\title{
Remuneration Provisions, Internal Governance and Risk Taking in Small Cooperative Banks
}

\author{
Maria Gaia Soana \\ Department of Economics and Management \\ University of Parma, Italy \\ Giovanni Ferri \\ Università LUMSA \\ Rome, Italy
}

\begin{abstract}
The CRD-IV Directive introduced some variable remuneration provisions in order to try to mitigate danger of excessive risk taking behaviour in the financial sector. While such approach makes sense for profit maximizing banks, it could be faulty to tame risk exposures of small cooperative banks (SCBs). We test our contention via unique data freshly assembled by an ad-hoc survey on manager compensation, internal governance and bank risk taking in Europe before and after the introduction of CRD-IV. Our results show that changes in remuneration schemes caused by this Directive did not induce less risk taking in SCBs. Our evidence also demonstrates that the changes in internal governance derived from the CRD-IV remuneration rules are not clearly associated with risk exposure. This evidence support the legislative proposals by the European Parliament in 2018 amending the current CRD-IV provisions about small financial firms.
\end{abstract}

Keywords: CRD-IV Directive; manager compensation; risk taking; small cooperative banks; internal governance

\section{Introduction}

Institutional reactions to the Great Financial Crisis (GFC) brought about in depth overhaul of rules and regulatory authorities. The main piece of new EU regulation was Directive 2013/36/EU (CRD-IV), passed in 2013. Besides incorporating the Basel III Accord prescriptions on capitalization, leverage, and liquidity, CRD-IV includes key innovations to banks manager compensation aiming to eradicate short-run profit incentives. The basic idea is that widespread use of compensation incentives related to short-run performance was a chief cause of banks excess risk exposures leading to the GFC. The Directive aims therefore to introduce some variable remunerations provisions, which may mitigate danger of excessive risk taking behaviour.

Among such provisions, CRD-IV requires deferral mechanisms of the actual payment of variable remuneration over a period that takes account of the underlying business cycle of the credit institution and its business risks. Furthermore, the Directive states that: (i) the assessment of the performance-based component of the remuneration should be based on long-term, accounting for current and future risks of that performance; (ii) the variable component of bank manager compensation shall not exceed the ratio of $1: 1$ of the fixed component of the total remuneration for each individual, and such ratio can be raised to a maximum of 2:1 only if a quorum of shareholders representing $50 \%$ of shares participates in the vote and a $66 \%$ majority of them supports the measure; (iii) at least $50 \%$ of any variable remuneration shall consist of a balance of shares or equivalent ownership interests and where possible bail-in-able instruments; and (iv) up to $100 \%$ of the total variable remuneration shall besides be subject to malus or clawback arrangements.

Therefore, CRD-IV remuneration provisions appear to be assessed on a performance basis and aligned with the risk appetite, values and long-term interests, in order to discourage manager excessive risk taking behaviour. In our opinion, while such approach makes sense for profit maximizing banks, it could be faulty to tame risk exposures of small cooperative banks (SCBs). First, by their mutual mission SCBs should not maximize profit - which, in any case, they cannot pay out as dividends - but the welfare of a wide set of stakeholders beside shareholders. Second, manager incentive-pay may be tiny at SCBs compared to other banks. Third, financial risk - creating short-run profit in the GFC, as usual - may be incommensurably smaller for SCBs vis-à-vis other banks. Our contention is consistent with the Opinion of the European Banking Authority (EBA, 2015, 2016) on the application of the principle of proportionality to the remuneration provisions in Directive 2013/36/EU, recommending that the CRD-IV be amended to allow for exemptions regarding the application of deferral arrangements, the pay out in instruments for small and non-complex institutions and for identified staff that receive only a low amount of variable remuneration when specific criteria are met. 
In this context, the European Commission published a number of proposed amendments to CRD-IV in November 2016, among which the provision on reducing the burden of the remuneration rules for smaller and less complex banking institutions and individuals with variable remuneration below certain thresholds. These rules feature in a suggested revision of the capital requirements directive CRD-IV, called CRD-V that, once approved by the European Parliament and Council of Ministers, is expected to take effect on 1 Jan 2021.

We test our contention via unique data, freshly assembled by an ad-hoc survey, on manager compensation, internal governance and banks risk taking in Europe before and after the introduction of CRD-IV. Our results show that changes in remuneration schemes caused by CRD-IV did not induce less risk taking in SCBs. Our evidence also demonstrates that the changes in internal governance derived from the Directive remuneration rules are not clearly associated with risk exposure.

The reminder of the paper is organized as follows. Section 2 reviews previous literature and explains the hypotheses. Section 3 describes the sample and the methodological approach. Section 4 reports the results of the estimation and the tests of the hypotheses, followed by the main conclusions in section 5 .

\section{Literature Review}

After the GFC, a debate has sparked among economists and regulators about the impact of bank corporate governance on risk taking. The general opinion is that excessive risk taking was at least in part caused by the large use of compensation incentives related to short-run performance and, in general, by weak internal governance systems.

In the last few years, financial regulators have underlined the importance of controlling bank risk-taking by reforming internal governance mechanisms (Liikanen et al., 2012; BIS, 2015; Bolton et al., 2015). Academic literature has consequently paid an increased attention to the role of internal governance in encouraging risky behaviour within the banking system.

Some studies investigate the impact of executive pay on bank risk taking, focusing exclusively on the U.S. banking sector, except for Vallascas and Hagendorff (2013) and the International Monetary Fund (IMF, 2014), that take into account also European banks. Chen et al., (2006) find a positive link between the percentage of option-based CEO wealth in total compensation and market-based measures of bank risk over the period 1992-2000. Moreover, Bai and Elyasiani (2013) show that, from 1992 to 2008, higher sensitivity to asset return volatility led to greater risk, measured by default risk and volatility of ROA. The positive relationship between sensitivity to asset return volatility and bank risk taking is also confirmed by Chesney et al. (2012) in the period 2007-2008. This evidence is reflected in the choice of bank policies. On this point, Hagendorff and Vallascas (2011) and DeYoung et al. (2013) demonstrate that higher option-induced incentives are positively related to riskier acquisitions and riskier investment policies, respectively.

Other studies focus on the nexus between equity-linked incentive pay and risk. Balachandran et al. (2011) find that more equity-based pay resulted in higher default risk in the period 1995-2008. On the contrary, the IMF (2014) shows that equity-linked and long-term incentive pay are associated with less risk in general, even if during the financial crisis equity awards were positively related to risk. The same held for restricted stock awards. Restricted equity awards are shown to lead to increased risk taking if the bank is close to default, but the opposite is true if the default probability is low because of managers' inability to diversify personal risk. The same analysis finds also evidence that a higher share of salary (fixed pay) is associated with higher risk in the small banks and the level of compensation (fixed plus variable) is not consistently related to risk taking.

Most empirical literature fails to show the existence of any statistically significant relationship between cash bonuses and risk (Fahlenbrach and Stulz, 2011; Vallascas and Hagendorff, 2013; Jokivuolle and Keppo, 2014). This is partially confirmed by the IMF (2014), testing that there is generally no relationship using cash bonuses as a percentage of total compensation, even if bonuses as a share of salary show a positive association with risk during the crisis.

Only a few studies have assessed the impact of CEO inside debt holdings (mainly pension benefits and deferred compensation) on bank risk taking. Tung and Wang (2011) find a negative relationship between inside debt holding and risk in the period 2007-2008. This relationship is confirmed also by Bennett et al. (2015), Bolton et al. (2015) and Bekkum (2016) that measure risk by means of market-based measure of default risk, CDS spreads and market volatility, respectively. Other studies test the linkage between risk governance and bank risk taking, almost exclusively using U.S. samples, except for Lingel and Sheedy (2012) and the IMF (2014), that consider a panel of international banks. The IMF (2014) provides evidence on the weak relationship between the existence of a board risk committee and risk in banks. Keys et al. (2009) show that the relative power of the risk manager (measured by the risk manager's share of the pay given to the top five compensated executives) has a negative effect on default rates of mortgage portfolios. 
Moreover, Aebi et al. (2012) find evidence that banks in which the Chief Risk Officer (CRO) directly reports to the board of directors and not to the CEO exhibit significantly higher stock returns and ROE in the period 2007-2008. Ellul and Yerramilli (2013) construct a risk management index to measure the strength and independence of the risk management function at bank holding companies. They show that strong and independent risk management function can curtail tail risk exposures at banks during the GFC. Such results are confirmed by Lingel and Sheedy (2012) using an international sample over the period 2004-2010.

Another research area investigates the impact of the ownership structure on bank risk taking. Laeven and Levine (2009) find a positive relationship between ownership concentration and risk taking, measured by default risk, aggregate risk, and volatility of operating returns, using a sample of international banks over the period 1996-2001. Such results are confirmed by Gropp and Köhler (2010) for the year 2008, estimating bank risk by means of deviation from the longterm average return on equity. Like Laeven and Levine (2009) and Gropp and Köhler (2010), also Beltratti and Shulz (2012) find that international banks with higher controlling shareholder ownership are riskier, as these banks had greater idiosyncratic risk and a lower distance to default before the crisis. Moreover, Erkens et al. (2012) find a positive relationship between institutional ownership and risk, measured by pre-crisis aggregate risk and expected default frequency, for the year 2008 on a sample of international banks. This evidence is not confirmed by Dolde and Knopf (2006) that show the negative impact of institutional ownership on aggregate risk and volatility of operating returns, using data for U.S. banks over the period 1990-2003. In addition, the IMF (2014) confirms these results using a sample of international banks. Other works investigate the nexus between inside ownership and bank risk taking. Such linkage seems to assume a U-shaped form in the studies by Dolde and Knopf (2006) and Forssbaeck (2011). Berger et al. (2014) focus specifically on the ownership by lower management, thus identifying a positive relationship between such variable and probability of default in the U.S. over the period 2007-2010.

A growing strand of literature analyses instead the differences in risk taking between stakeholder-oriented banks identified by cooperative banks and savings banks - and shareholder-oriented banks - identified by for profit commercial and investment banks. Iannotta et al. (2007) find mutual banks (approximately coinciding with stakeholder banks) to have higher loan quality than shareholder banks. Just before the crisis, Hesse and Ĉihák (2007) released a study indicating that cooperative banks had much lower variability in profits than other banks, and for this reason, they enjoyed higher distance-to-default z-scores. Their findings have been employed to argue that cooperative banks are more stable during a crisis, despite that their data ended well before the crisis began.

There is much less research in this area using European data from actual crisis period, and these studies often make relatively strong claims regarding the performance differences since the onset of the subprime crisis. For instance, Smolders et al. (2012) state that European cooperative banks have generally performed better than average in weathering the GFC. Analysing a large sample of European banks over 1996-2011, Ferri et al. (2015) find that stakeholder banks had higher loan quality before and during the crisis and, with the exception of private savings banks, profitability and loan quality of stakeholder banks has improved relative to that of general shareholder banks during the crisis years.

In order to discourage manager excessive risk taking behaviour, CRD-IV passed in 2013 requires adequate remuneration policies, as suggested by the above-mentioned literature. Such policies must take into account some variable remunerations provisions assessed on a performance basis and aligned with the risk appetite, values and longterm interests. This approach is certainly adequate for medium-large and profit maximizing banks, but may be faulty to tame risk exposures of SCBs, which during the crisis were more stable and had higher performance and better loan quality than other banks. SCBs aim indeed to maximize the welfare of a wide set of stakeholders instead of just shareholders' profit. Moreover, manager incentive-pay and financial risk (creating short-run profit in the GFC) may be incommensurably smaller at SCBs than other banks.

In this context, we test the following hypothesis:

$\mathrm{H}_{1}$ : Changes in remuneration schemes caused by CRD-IV induce less risk-taking in medium-large banks rather than in SCBs.

In order to promote sound and effective risk management, CRD-IV requires also adequate internal control mechanisms. This is consistent with previous literature demonstrating the existence of a positive relationship between high quality internal governance (and, especially, risk governance) and risk taking. In order to examine potential benefits of CRDIV provision on internal control systems, we formulate the following hypothesis:

$\mathrm{H}_{2}$ : High quality internal governance is negatively associated with bank risk-taking. 


\section{Sample, Methodology, and Data}

\subsection{Sample}

There may be multiple links between remuneration policies and risk taking. However, due to the difficulties in finding these data, our main constraint is represented by the availability of information on bank remuneration policies and whether and to what extent these policies started changing in recent years. That change is expected as a reaction to both market increased attention to this aspect of bank internal management and, even more so, to the introduction in 2013 of the new CRD-IV Directive prescribing stricter rules on bank managers compensation.

We collected data on manager compensation, internal governance and risk taking before and after the introduction of CRD-IV by an ad-hoc questionnaire. The survey was sent via email by the institute for financial services (Iff, based in Hamburg) to a large sample of HR departments of European banks and investment firms in the fall of 2015. The completed questionnaires were returned by 195 European banks between October and December 2015.

From the survey, we obtain information on the evolution between 2010 and 2014 of three key dimensions of bank remuneration policies. Namely, we focus on the following three variables, as declared by the banks themselves: (i) change in the variable share remuneration (D_varrem); (ii) change in the variable share paid in cash (D_varb) and (iii) change in the deferred variable share in cash (D_def_var). In the CRD-IV spirit, beneficial effects in terms of lowering risk taking are expected from: i) reducing the variable share remuneration (D_varrem < 0); ii) reducing the variable share paid in cash (D_varb $<0)$; iii) increasing the deferred variable share in cash (D_def_var $>0$ ).

Ten specific questions were structured in order to measure internal governance quality of banks. High-quality internal governance was measured by the following 10 items: (i) CRO has significant input into performance reviews of business heads; (ii) CRO has significant input into performance reviews of identified staff; (iii) review of identified staff has received effective added value (inputs, information, suggestions) from the remuneration committee; (iv) review of identified staff has received effective added value (inputs, information, suggestions) from the nomination committee; (v) the supervisory function is effectively challenging risk-related decisions of the executive directors; (vi) there are effective controls at the business level; (vii) there are effective controls at the control function level; (viii) the banks uses sophisticated models to measure risk; (ix) there is significant training on risk appetite and the implications for non-compliance, and (x) the board and senior managers specify what risk level is acceptable to the firm. Answers were classified according to a 5-item Likert scale: 1 (strongly disagree); 2 (disagree); 3 (neither agree nor disagree); 4 (agree) and 5 (strongly agree). We construct the variable internal governance quality (intern_gov_q) as the sum of the 10 scores above. The value of such variable varies in theory from a maximum of 50 and a minimum of 0 . The effective data in our bank sample has a mean of 28.7, a median of 28.0, a maximum of 50 and a minimum of 4 .

In addition, we introduced the following two dummy variables: high-quality internal governance (GOOD_GOV), which takes value 1 if intern_gov_q $>=35$ (equal to the value of the $75^{\text {th }}$ centile) and 0 otherwise, and low-quality internal governance (BAD_GOV), which takes value 1 if intern_gov_q $<=24$ (equal to the value of the $25^{\text {th }}$ centile) and 0 otherwise.

\subsection{Methodology}

We first estimate OLS specifications and then logit and ordered logit specifications introducing our three variables capturing the change in bank remuneration policies that become our main explanatory variables. In turn, the dependent variables are either four individual standard measures of risk taking - or a transformation of them (in the logit and ordered logit specification). Specifically, we consider four key variables, again in their change between 2010 and 2014, extracted from Bankscope: (i) D_RWA = change in Risk Weighted Assets; (ii) D_Impaired loans/Gross loans = change in the ratio of impaired loans to gross loans; (iii) D_Res_impaired_loans/Gross loans $=$ change in the ratio of reserves on impaired loans to gross loans; and D_Equity/Total assets = change in the ratio of equity to total assets.

Our OLS regression equations take the following form:

D_RISK ${ }_{\mathrm{i}}=\mathrm{a}_{0}+\mathrm{a}_{1} \mathrm{xD}$ _REMPOL ${ }_{\mathrm{i}}+\mathrm{a}_{2} \mathrm{xD} \mathrm{REMPOL}_{\mathrm{i}}^{2}+\mathrm{a}_{3} \mathrm{x} \mathrm{SIZE}_{\mathrm{i}}+\mathrm{a}_{4} \mathrm{xD} \_\mathrm{REMPOL}_{\mathrm{i}} \mathrm{x} \mathrm{SIZE}_{\mathrm{i}}+$

$+\mathrm{a}_{5} \mathrm{xD} \_$REMPOL ${ }_{\mathrm{i}}^{2} \mathrm{xSIZE_{i }}+\mathrm{a}_{6} \mathrm{xGER}_{\mathrm{i}}+\mathrm{a}_{7} \mathrm{xITA} \mathrm{A}_{\mathrm{i}}+\mathrm{a}_{8} \mathrm{xBCC} \mathrm{C}_{\mathrm{i}}+\mathrm{a}_{9} \mathrm{xD} \_\mathrm{REMPOL}_{\mathrm{i}} \mathrm{xBCC} \mathrm{C}_{\mathrm{i}}+$

$+\mathrm{a}_{10} \mathrm{xD} \_$REMPOL ${ }_{\mathrm{i}}^{2} \mathrm{xBCC} \mathrm{i}_{\mathrm{i}}+\mathrm{a}_{11} \mathrm{xGOOD} \mathrm{GOV}_{\mathrm{i}}+\mathrm{a}_{11} \mathrm{xBAD} \mathrm{GOV}_{\mathrm{i}}+\varepsilon_{\mathrm{i}}$

where each variable is indexed by $i$ since it refers to individual bank $i$; the dependent variable $\mathrm{D}_{-} \mathrm{RISK} \mathrm{i}_{\mathrm{i}}$ will, in turn, be D_RWA, D_Impaired loans/Gross loans, D_Res_impaired_loans/Gross loans, or D_Equity/Total assets; D_REMPOL will, in turn, be D_varrem, D_varb, or D_def_var. The variable SIZE, the logarithm of total assets, is introduced since remuneration policies likely differ according to the dimension of the bank. GER is a dummy taking the value of 1 if the bank is from Germany and zero otherwise; ITA is a dummy taking the value of 1 if the bank is from Italy and zero otherwise (where Germany, and especially Italy, are the two countries more represented in the sample survey); 
BCC is a dummy taking the value of 1 if the bank is a Banca di Credito Cooperativo (a category of small mutual cooperative banks that was particularly oversampled: 129 banks over a total of 195 banks for the whole of Europe), and zero otherwise. The remuneration policy explanatory variables were introduced with both a linear and a quadratic term. This was meant to capture potential nonlinearities in the link between compensation decisions and risk taking. In addition, both these variables were also interacted with SIZE since those nonlinearities might change with banks dimension.

Finally, those interactions were also created with the BCC dummy. In practice, having cleaned the Banche di Credito Cooperativo observations with the ITA dummy, we want to let the specificities of the relationship between remuneration policies and risk taking at these banks to fully emerge. To this end, we allow these banks to have both a shift effect, as measured by BCC adding to the constant, and an effect on the slope of the impact of remuneration policies on risk taking. We now turn to the logit and ordered logit specifications. The chief advantage of using this, alternative, limited dependent variable approach is simply explained. In practice, we may suspect that several of the dependent variables are imprecisely measured and this could bias our econometric results. As such, reshaping our analysis in terms of a logit or ordered logit model should reduce that risk. Specifically, we define a variable of good performance $\left(G O O D \_P E R F O R M_{i}\right.$ ) in the following fashion. For each of the four risk variables we have, we consider as good performing banks those that achieve a realization beyond the worst quartile threshold. In practice, this works as follows:

GOOD_PERFORM ${ }_{i}=1$ if bank i has: (i) D_RWA $<=5.86$, where 5.86 is the rate of growth of RWA at the $75^{\text {th }}$ centile; (ii) D_Impaired loans/Gross loans $<=169.85$, where 169.85 is the rate of growth of the Impaired loans/Gross loans ratio at the $75^{\text {th }}$ centile; (iii) D_Res_impaired_loans/Gross loans $>=41.36$, where 41.36 is the rate of growth of the Res_impaired_loans/Gross loans ratio at the $25^{\text {th }}$ centile (we interpreted low growth of the reserves as a less prudent behavior); and (iv) D_Equity/Total assets $>=-14.02$, where -14.02 is the rate of growth of the Equity/Total assets ratio at the $25^{\text {th }}$ centile. Then, only a bank satisfying jointly these four conditions is assigned a value of 1 , while the others are given zero. The incidence of banks having good performance according to this criterion is 17.4 per cent. GOOD_PERFORM $_{\mathrm{i}}$ will be our dependent variable in the logit specifications that will consider as explanatory variables the same set of independent variables listed in equation (1).

As a further check, we introduced an ordered logit specification built as follows. We built an ordered dependent variable (DEGREE_GOOD_PERFORM ${ }_{\mathrm{i}}$ ) that takes value 1 if only the first condition of GOOD_PERFORM $\mathrm{M}_{\mathrm{i}}$ is satisfied - i.e., D_RWA $<=5.86$-, takes value 2 if also the second condition - D_Impaired loans/Gross loans $<=169.85-$ is achieved, takes value 3 if also the third condition - D_Res_impaired_loans/Gross loans $>=41.36$ - attains, and takes value 4 if also the fourth condition - D_Equity/Total assets>=-14.02 - is reached. In other words, those banks that have GOOD_PERFORM $_{\mathrm{i}}=1$ will have DEGREE_GOOD_PERFORM $\mathrm{i}_{\mathrm{i}}=4$, while we let our regression take care also of intermediate situations where less than four but one, two, or three of the conditions are satisfied. In view of the fact that risk taking is a multidimensional concept, we believe this approach may help our understanding of the phenomenon under study. DEGREE_GOOD_PERFORM ${ }_{i}$ will be our dependent variable in the ordered logit estimation where the explanatory variables will be the same set of independent variables as in the logit specifications.

\subsection{Data}

Table 1 lists all the variables that we considered in our various specifications. The first six rows contain the performance variables that will alternatively appear as dependent variables. Row seven specifies the BCC dummy identifying the "Banche di Credito Cooperativo", i.e. the small-sized mutual cooperative banks operating in Italy. Thanks to the high representation of these banks in the Iff survey, we can explore whether remuneration policies attain different results at these banks with respect to the other banks. Namely, we will try to assess that through the interactions of BCC with the remuneration policy independent variables - see rows from 34 to 39. 
Table 1. Variable Description

\begin{tabular}{|c|c|}
\hline Variable & Description \\
\hline \multicolumn{2}{|l|}{ Dependent Variables } \\
\hline 1. D_RWA & Change of Risk Weighted Assets from 2010 to 2014 (per cent) \\
\hline 2. D_Impaired loans/ Gross loans & Change of the ratio Impaired loans/Gross loans from 2010 to 2014 (per cent) \\
\hline $\begin{array}{l}\text { 3. D_Res_impaired_loans/ } \\
\text { Gross loans }\end{array}$ & Change of the ratio Reserves on impaired loans/Gross loans from 2010 to 2014 (per cent) \\
\hline 4. D_Equity/Total assets & Change of the ratio Equity/Total assets from 2010 to 2014 (per cent) \\
\hline 5. Good_performance & $\begin{array}{l}\text { Dummy variable taking value } 1 \text { if D_RWA }<=5.86-\text { the value at the } 75^{\text {th }} \text { centile }- \text { and } \\
\text { D_Impaired loans/Gros loans }<=169.85-\text { the value at the } 75^{\text {th }} \text { centile }- \text { and } \\
\text { D_Res_impaired_loans/Gross loans }>=41.36-\text { the value at the } 25^{\text {th }} \text { centile }- \text { and } \\
\text { D Equity/Total assets }>=-14.02-\text { the value at the } 25^{\text {th }} \text { centile }\end{array}$ \\
\hline 6. Degree of Good_performance & $\begin{array}{l}\text { Graduated dummy variable valued } 1 \text { if D_RWA }<=5.86-75^{\text {th }} \text { centile }- \text { valued } 2 \text { if also } \\
\text { D_Impaired loans/Gross loans }<=169.85-75^{\text {th }} \text { centile }- \text { valued } 3 \text { if also } \\
\text { D_Res_impaired_loans/Gross loans }>=41.36-25^{\text {th }} \text { centile }- \text { valued } 4 \text { if also D_Equity/Total } \\
\text { assets }>=-14.02-25^{\text {th }} \text { centile }\end{array}$ \\
\hline \multicolumn{2}{|l|}{ Independent variables } \\
\hline 7. $\mathrm{BCC}$ & Dummy variable taking value 1 if the bank is a Banca di Credito Cooperativo \\
\hline 8. Austria & Dummy variable taking value 1 if the bank is from Austria \\
\hline 9. Denmark & Dummy variable taking value 1 if the bank is from Denmark \\
\hline 10. Finland & Dummy variable taking value 1 if the bank is from Finland \\
\hline 11. France & Dummy variable taking value 1 if the bank is from France \\
\hline 12. Germany & Dummy variable taking value 1 if the bank is from Germany \\
\hline 13. Ireland & Dummy variable taking value 1 if the bank is from Ireland \\
\hline 14. Italy & Dummy variable taking value 1 if the bank is from Italy \\
\hline 15. Luxembourg & Dummy variable taking value 1 if the bank is from Luxembourg \\
\hline 16. Malta & Dummy variable taking value 1 if the bank is from Malta \\
\hline 17. Netherlands & Dummy variable taking value 1 if the bank is from the Netherlands \\
\hline 18. Poland & Dummy variable taking value 1 if the bank is from Poland \\
\hline 19. Sweden & Dummy variable taking value 1 if the bank is from Sweden \\
\hline 20. United Kingdom & Dummy variable taking value 1 if the bank is from the UK \\
\hline 21. D_varrem & Change in the variable share remuneration from 2010 to 2014 \\
\hline 22. D_varrem2 & Squared of D_varrem \\
\hline 23. D_varb & Change in the variable share paid in cash from 2010 to 2014 \\
\hline 24. D_varb2 & Squared of D_varb \\
\hline 25. D_def_var & Change in the deferred variable share in cash from 2010 to 2014 \\
\hline 26. D_def_var2 & Squared of D_def_var \\
\hline 27. Size & Logarithm (base 10) of total assets \\
\hline 28. D_varrem_size & Interaction between D_varrem and Size \\
\hline 29. D_varrem2_size & Squared of D_varrem_size \\
\hline 30. D_varb_size & Interaction between D_varb and Size \\
\hline 31. D_varb2_size & Squared of D_varb_size \\
\hline 32. D_def_var_size & Interaction between D_def_var and Size \\
\hline 33. D_def_var_size2 & Squared of D_def_var_size \\
\hline 34. D_varrem_Bcc & Interaction between D_varrem and BCC \\
\hline 35. D_varrem2_Bcc & Squared of D_varrem_Bcc \\
\hline 36. D_varb_Bcc & Interaction between D_varb and BCC \\
\hline 37. D_varb2_Bcc & Squared of D_varb_Bcc \\
\hline 38. D_def_var_Bcc & Interaction between D_def_var and BCC \\
\hline 39. D_def_var2_Bcc & Squared of D_def_var_Bcc \\
\hline 40. Good_gov & $\begin{array}{l}\text { Dummy variable taking value } 1 \text { if the bank has a quality of internal governance }>=35 \text { - the value } \\
\text { at the } 75^{\text {th }} \text { centile }\end{array}$ \\
\hline 41. Bad_gov & $\begin{array}{l}\text { Dummy variable taking value } 1 \text { if the bank has a quality of internal governance }<=24-\text { the value } \\
\text { of the } 25^{\text {th }} \text { centile }\end{array}$ \\
\hline
\end{tabular}

Source: Authors 
Rows from 8 to 20 list the country dummy variables for the 13 countries covered by the survey. Unfortunately, due to the limited numbers of observations for most of the countries, only the dummy for Germany and that for Italy could be included in some of the estimations. Rows 21, 23, and 25 list the three remuneration policy variables measured in the Iff survey: (i) change in the variable share remuneration (D_varrem); (ii) change in the variable share paid in cash (D_varb) and (iii) change in the deferred variable share in cash (D_def_var). In turn, the variables in rows 22, 24, and 26 are the squared terms of the three remuneration policy variables. Their inclusion aims to capture potential nonlinearities in the impact of remuneration policies on banks' risk taking. Row 27 lists Size, following the idea that risk taking might differ across banks' dimensional spectrum. As for BCC, we introduce interaction terms between Size and the three remuneration policy measures - see rows from 28 to 33. Finally, rows 40, and 41 list, respectively, Good_gov and Bad_gov, the two dummies encapsulating the quality of internal governance of a bank.

Table 2. Summary statistics

\begin{tabular}{|c|c|c|c|c|c|}
\hline Variables & $\begin{array}{l}\text { Number } \\
\text { Observations }\end{array}$ & Mean & $\begin{array}{l}\text { Standard } \\
\text { Deviation }\end{array}$ & Min & Max \\
\hline \multicolumn{6}{|l|}{ Dependent Variables } \\
\hline 1. D_RWA ${ }^{\mathrm{a}}$ & 142 & 0.26 & 22.29 & -40.15 & 113.11 \\
\hline 2. D_Impaired loans/Gross loans ${ }^{a}$ & 143 & 121.26 & 132.33 & -74.40 & 850.00 \\
\hline 3. D_Res_impaired_loans/Gross loans ${ }^{\text {a }}$ & 145 & 215.66 & 251.99 & -75.46 & 1533.82 \\
\hline 4. D_Equity/Total assets ${ }^{\text {a }}$ & 165 & 1.96 & 33.44 & -45.15 & 259.57 \\
\hline 5. Good_performance ${ }^{\wedge}$ a & 137 & 0.73 & 0.45 & 0.00 & 1.00 \\
\hline 6. Degree of Good_performance ${ }^{a}$ & 137 & 2.99 & 0.80 & 1.00 & 4.00 \\
\hline \multicolumn{6}{|l|}{ Independent variables } \\
\hline 7. $\mathrm{BCC}^{\wedge} \mathrm{b}$ & 195 & 0.66 & 0.47 & 0.00 & 1.00 \\
\hline 8. Austria ${ }^{\wedge} \mathrm{b}$ & 195 & 0.02 & 0.12 & 0.00 & 1.00 \\
\hline 9. Denmark $^{\wedge} \mathrm{b}$ & 195 & 0.01 & 0.10 & 0.00 & 1.00 \\
\hline 10. Finland ${ }^{\wedge} \mathrm{b}$ & 195 & 0.01 & 0.10 & 0.00 & 1.00 \\
\hline 11. France $\mathrm{A}^{\mathrm{b}}$ & 195 & 0.02 & 0.12 & 0.00 & 1.00 \\
\hline 12. Germany^ ${ }^{\wedge}$ & 195 & 0.08 & 0.27 & 0.00 & 1.00 \\
\hline 13. Ireland ${ }^{\wedge} \mathrm{b}$ & 195 & 0.02 & 0.12 & 0.00 & 1.00 \\
\hline 14. Italy $^{\wedge} \mathrm{b}$ & 195 & 0.68 & 0.47 & 0.00 & 1.00 \\
\hline 15. Luxembourg $\wedge^{\wedge}$ & 195 & 0.02 & 0.14 & 0.00 & 1.00 \\
\hline 16. Malta $^{\wedge}{ }^{b}$ & 195 & 0.02 & 0.14 & 0.00 & 1.00 \\
\hline 17. Netherlands ${ }^{\wedge}{ }^{b}$ & 195 & 0.03 & 0.16 & 0.00 & 1.00 \\
\hline 18. Poland ${ }^{\wedge} \mathrm{b}$ & 195 & 0.03 & 0.16 & 0.00 & 1.00 \\
\hline 19. Sweden^ ${ }^{b}$ & 195 & 0.01 & 0.10 & 0.00 & 1.00 \\
\hline 20. United Kingdom ${ }^{\wedge}$ b & 195 & 0.03 & 0.16 & 0.00 & 1.00 \\
\hline 21. D_varrem ${ }^{b}$ & 118 & -0.04 & 0.10 & -0.39 & 0.18 \\
\hline 22. D_varrem $2^{\mathrm{b}}$ & 118 & 0.01 & 0.03 & 0.00 & 0.16 \\
\hline 23. D_varb ${ }^{\mathrm{b}}$ & 119 & -0.01 & 0.20 & -0.50 & 1.71 \\
\hline 24. D_varb $2^{b}$ & 119 & 0.04 & 0.27 & 0.00 & 2.94 \\
\hline 25. D_def_var ${ }^{b}$ & 118 & 0.04 & 0.17 & -0.33 & 1.40 \\
\hline 26. D_def_var2 ${ }^{b}$ & 118 & 0.03 & 0.19 & 0.00 & 1.97 \\
\hline 27. Size ${ }^{b}$ & 189 & 3.82 & 2.40 & 0.00 & 10.94 \\
\hline 28. D_varrem_size ${ }^{\text {b }}$ & 118 & -0.25 & 0.79 & -3.89 & 1.40 \\
\hline 29. D_varrem2_size ${ }^{b}$ & 118 & 0.08 & 0.25 & 0.00 & 1.46 \\
\hline 30. D_varb_size ${ }^{b}$ & 119 & -0.04 & 1.61 & -4.00 & 14.25 \\
\hline 31. D_varb2_size ${ }^{b}$ & 119 & 0.32 & 2.27 & 0.00 & 24.42 \\
\hline 32. D_def_var_size ${ }^{\mathrm{b}}$ & 118 & 0.21 & 0.92 & -2.74 & 5.14 \\
\hline 33. D_def_var_size ${ }^{b}$ & 118 & 0.16 & 0.75 & 0.00 & 7.22 \\
\hline 34. D_varrem_Bcc ${ }^{\text {b }}$ & 118 & -0.01 & 0.04 & -0.25 & 0.11 \\
\hline 35. D_varrem2_Bcc ${ }^{b}$ & 118 & 0.00 & 0.01 & 0.00 & 0.06 \\
\hline 36. D_varb_size_Bcc ${ }^{b}$ & 119 & 0.00 & 0.00 & 0.00 & 0.00 \\
\hline 37. D_varb_size 2_Bcc ${ }^{\text {b }}$ & 119 & 0.00 & 0.00 & 0.00 & 0.00 \\
\hline 38. D_def_var_Bcc ${ }^{\mathrm{b}}$ & 118 & 0.01 & 0.13 & -0.14 & 1.40 \\
\hline 39. D_def_var2_Bcc ${ }^{b}$ & 118 & 0.02 & 0.18 & 0.00 & 1.97 \\
\hline
\end{tabular}



40. Good_gov^ ${ }^{\mathrm{b}}$
195
0.35
0.48
$0.00 \quad 1.00$
41. Bad_gov^ ${ }^{\mathrm{b}}$
195
$0.24 \quad 0.43$
$0.00 \quad 1.00$

Note: ${ }^{\wedge}$ denotes a $(0,1)$ dummy variable. Sources: ${ }^{a}=$ BankScope $;{ }^{b}=$ Iff survey.

Besides, Table 2 presents basic descriptive statistics for each one of the variables. Regarding the risk taking variables, they all grew at the mean with the largest growth for D_Res_impaired_loans/Gross loans followed by D_Impaired loans/Gross loans, by D_Equity/Total assets, and by D_RWA. Good_performance is achieved by almost three fourths of the banks while the Degree of Good_performance reaches a mean value of 2.99 out of the maximum value of 4 .

Row seven confirms that two thirds of our sample consists of Banche di Credito Cooperativo. The country dummies are above 3 per cent only for Germany ( 8 per cent) and Italy (68 per cent), which explains why only these two will be employed in some of the regressions.

Rows 21, 23, and 25 show that from 2010 to 2014 each of the three remuneration policy variables measured in the Iff survey moved in the "right" way on average: (i) the variable share remuneration decreased by 4 per cent; (ii) the variable share paid in cash declined by 1 per cent; and (iii) the deferred variable share in cash increased by 4 per cent. It should be noted that the largest moves in the "right" way reported a 39\% reduction in the variable share remuneration, a halving of the variable share paid in cash, and an increase of 140 per cent of the deferred variable share in cash.

Regarding Size - row 27 - we find that the average bank has just $€ 45.6$ millions of total assets with the minimum-sized bank having as little as $€ 2$ million and the largest-sized responding bank reaching instead $€ 56.2$ billion. Of course, the average is heavily affected by the fact that $2 / 3$ of the banks are tiny mutual cooperative banks. Finally, Good_gov and Bad_gov regard, respectively, 35 and 24 per cent of our banks.

\section{Main results}

The results of the OLS estimations are reported in Tables 3, 4 and 5, respectively referring to the change in variable share remuneration over 2010-2014 (D_varrem), to the change in variable share paid in cash over 2010-2014 (D_varb), and to the change in deferred variable share in cash over 2010-2014 (D_def_var),

We can start noticing that the change in variable remuneration share is never a significant determinant of changes in risk taking. Neither the linear term D_varrem nor its squared nor their interactions with Size and BCC ever reach statistical significance. From Table 3 we may notice that the growth of the ratio of reserves on impaired loans to gross loans is systematically smaller for banks that show weaker internal governance. Finally, we detect systematically higher increases in the Equity/Total assets ratio for German banks and for banks having a good internal governance.

Table 3 OLS Regression on D_varrem (delta variable share remuneration over 2010-14)

\begin{tabular}{|l|l|l|l|l|}
\hline \multicolumn{7}{|l|}{ Dependent variables } \\
\hline Regressors & D_RWA & $\begin{array}{l}\text { D_Impaired loans/ } \\
\text { Gross loans }\end{array}$ & $\begin{array}{l}\text { D_Res_impaired_loans/ } \\
\text { Gross loans }\end{array}$ & $\begin{array}{l}\text { D_Equity/ } \\
\text { Total assets }\end{array}$ \\
\hline D_varrem & 207.089 & -212.586 & 959.861 & 184.099 \\
\hline D_varrem & 528.121 & 3019.687 & 4774.788 & 503.894 \\
\hline Size & -0.143 & 10.913 & -14.076 & 3.224 \\
\hline D_Varrem_Size & -24.604 & 56.785 & -97.365 & -1.366 \\
\hline D_Varrem_Size & -63.202 & -276.314 & -510.864 & -32.486 \\
\hline Germany & 7.066 & -20.285 & -52.017 & $30.899^{* *}$ \\
\hline Italy & -12.941 & 3.482 & 104.413 & -52.964 \\
\hline Bcc & 12.765 & 150.480 & 103.334 & 28.484 \\
\hline D_Varrem_Bcc & -126.907 & 159.961 & -283.154 & -119.361 \\
\hline D_Varrem_Bcc & -622.442 & -3418.838 & -2575.897 & 84.185 \\
\hline Good_gov & 5.330 & 14.170 & 50.709 & $15.852^{*}$ \\
\hline Bad_gov & 6.908 & -29.081 & -134.254 & 1.335 \\
\hline Constant & -0.504 & -15.328 & 157.665 & 3.119 \\
\hline No. observations & 94 & 95 & 95 & 105 \\
\hline F-test & 1.290 & 3.160 & 4.810 & 4.950 \\
\hline R-squared & 0.039 & 0.141 & 0.241 & 0.255 \\
\hline
\end{tabular}

Source: authors*, **, *** denote the statistical significance at 10\%, $5 \%$ and 1\%, respectively 
Turning to Table 4, we seem to find some evidence of a significant link between the change in variable share paid in cash and the concurrent change in the Equity/Total assets ratio. Both the linear and the quadratic term are significant. The negative coefficient confirms that increasing the variable share paid in cash is associated with lower bank capitalization. In this respect, since we saw that banks reduced the variable share paid in cash between 2010 and 2014, the evolution of remuneration policies favoured by CRD-IV might have contributed to increase the capitalization of banks. However, it is also interesting to notice that the coefficient of the interaction of D_varb with Size - and also the interaction of the squared term - is positive and significant. This seems to suggest that curbing the variable share paid in cash achieved less important effects in terms of promoting capitalization at larger-sized banks. Unfortunately, due to lack of observations on this variable, the coefficients for the interaction terms between D_varb - and its square - and BCC cannot be estimated. From Table 4 we also learn that larger-sized banks tended to increase their reserves on impaired loans/gross loans ratios less than the other banks, something we detect as well for German banks whose economy had a comparatively better performance between 2010 and 2014. Macroeconomic trends help explain also the fact that Italian banks had a higher growth of their impaired loans/gross loans ratios, a higher increase in reserves on impaired loans/gross loans ratios and a lower increase in equity/total assets ratios. Finally, banks enjoying good internal governance managed to achieve more progress in terms of their equity/total assets ratios.

Table 4 OLS Regression on D_varb (delta variable share paid in cash over 2010-14)

\begin{tabular}{|l|l|l|l|l|}
\hline & \multicolumn{2}{|l|}{ Dependent variables } \\
\hline Regressors & D_RWA & $\begin{array}{l}\text { D_Impaired } \\
\text { loans/Gross loans }\end{array}$ & $\begin{array}{l}\text { D_Res_impaired_ } \\
\text { loans/Gross loans }\end{array}$ & $\begin{array}{l}\text { D_Equity/Total } \\
\text { assets }\end{array}$ \\
\hline D_varb & 726.652 & 14.750 & 192.281 & $-886.566^{* *}$ \\
\hline D_varb ${ }^{2}$ & 1421.413 & -138.888 & -904.463 & $-1985.582^{* *}$ \\
\hline Size & -1.988 & -4.001 & $-30.614^{* *}$ & 2.838 \\
\hline D_Varb_Size & -90.363 & 3.881 & -18.281 & $110.145^{* *}$ \\
\hline D_Varb__Size & -184.851 & -26.280 & 73.022 & $235.674^{* *}$ \\
\hline Germany & -1.820 & -51.410 & $-106.615^{* * *}$ & 19.712 \\
\hline Italy & -13.445 & $99.142^{* *}$ & $95.542^{*}$ & $-26.280^{* *}$ \\
\hline Bcc & 4.628 & -31.976 & -8.545 & 4.991 \\
\hline D_Varb_Size_Bcc & Omitted & Omitted & Omitted & Omitted \\
\hline D_Varb_Size ${ }^{2}$ Bcc & Omitted & Omitted & Omitted & Omitted \\
\hline Good_gov & 4.937 & 11.847 & 33.779 & $15.531^{* *}$ \\
\hline Bad_gov & -0.053 & -25.527 & -123.408 & 5.913 \\
\hline Constant & 15.422 & 94.110 & 295.227 & 0.088 \\
\hline No. observations & 98 & 99 & 99 & 107 \\
\hline F-test & 1.470 & $11.920^{* * *}$ & $28.410^{* * *}$ & $8.840^{* * * *}$ \\
\hline R-squared & 0.067 & 0.135 & 0.213 & 0.226 \\
\hline
\end{tabular}

Source: authors $\quad *, * *, * * *$ denote the statistical significance at 10\%, 5\% and 1\%, respectively

Some interesting results emerge also from Table 5. Though the change in deferred variable share in cash is never significant directly, some of its interaction terms turn out statistically significant. This is the case of the D_RWA estimation, where the interaction of D_def_var2 with SIZE has a positive and significant coefficient suggesting that, contrary to what expected, larger banks increasing recourse to cash payment deferrals increased their risk taking more than the other banks. Interacting D_def_var with BCC delivers also contradictory results. The linear term interaction bears a significant coefficient with the expected negative sign - more deferral, less risk taking - but the squared term interaction delivers a significant coefficient with a positive sign. Thus, the overall effect is given by the sum of the two impacts. At the mean, the quadratic impact $(+20.1 \%)$ dominates the linear impact $(-10.2 \%)$. Thus, unfortunately, for the Banche di Credito Cooperativo more deferral seems to be associated with more, not less, risk taking in terms of RWA. As to the other significant results from Table 5, it is confirmed that Italian banks had a higher growth of their impaired loans/gross loans ratios, a higher increase in reserves on impaired loans/gross loans ratios and a lower increase in equity/total assets ratios. Finally, banks with good internal governance succeeded to increase their equity/total assets ratios more than the other banks. 
Table 5 OLS Regression on D_def_var (delta deferred variable share in cash over 2010-14)

\begin{tabular}{|l|l|l|l|l|}
\hline \multicolumn{5}{|l}{ Dependent variables } \\
\hline Regressors & D_RWA & $\begin{array}{l}\text { D_Impaired } \\
\text { loans/Gross loans }\end{array}$ & $\begin{array}{l}\text { D_Res_impaired_ } \\
\text { loans/Gross loans }\end{array}$ & $\begin{array}{l}\text { D_Equity/ } \\
\text { Total assets }\end{array}$ \\
\hline D_def_var & 676.952 & -1294.358 & -113.849 & -507.168 \\
\hline D_def_var ${ }^{2}$ & -1762.432 & 3223.396 & -781.403 & 1111.736 \\
\hline Size & -1.103 & 2.926 & -22.946 & 0.485 \\
\hline D_def_var_Size & -90.354 & 146.528 & -28.407 & 54.089 \\
\hline D_def_var_Size & $267.116^{*}$ & -424.923 & 212.628 & -127.625 \\
\hline Germany & -4.036 & -9.666 & -71.790 & 21.698 \\
\hline Italy & -23.689 & $103.270^{* * *}$ & $110.458^{* *}$ & $-28.971^{*}$ \\
\hline Bcc & 21.156 & 40.457 & 54.219 & -1.792 \\
\hline D_def_var_Bcc & $-875.908^{* *}$ & -1391.669 & -1972.739 & 345.589 \\
\hline D_def_var _Bcc & $1185.309^{*}$ & -168.385 & 1450.110 & -678.666 \\
\hline Good_gov & 4.568 & 25.053 & 29.449 & $16.014^{* *}$ \\
\hline Bad_gov & 3.846 & -9.446 & $-111.025^{* *}$ & 2.043 \\
\hline Constant & 3.555 & 7.709 & 224.754 & 16.806 \\
\hline No. observations & 99 & 99 & 99 & 106 \\
\hline F-test & $71.450^{* * * *}$ & $5.650^{* * * *}$ & 7.820 & $58.430^{* * * *}$ \\
\hline R-squared & 0.307 & 0.213 & 0.253 & 0.266 \\
\hline Source: & & $109,5 \%$ & \\
\hline
\end{tabular}

Source: authors ${ }^{*},{ }^{* *},{ }^{* * * *}$ denote the statistical significance at $10 \%, 5 \%$ and $1 \%$, respectively

The results obtained from the OLS regressions are partly confirmed on qualitative grounds by the logit and ordered logit specifications. In particular, Table 6 shows the following main results. First, reducing the variable share remuneration and increasing the deferred variable share in cash increases the probability that a bank has good performance. This is obvious for D_varrem, where both the linear and the quadratic term have significant coefficients with a negative sign, but is true also for D_def_var if one considers that between the two significant coefficients, the positive quadratic one dominates the negative linear one. However, the two next results are contradictory. Second, in fact, increasing, not decreasing, variable remuneration raises the probability of having good performance for the largersized banks, while for these banks in terms of D_def_var, again, the quadratic coefficient dominates the linear one but with, respectively negative and positive signs. And, third, analogous reasoning attains for the BCC banks. Here, in fact, contrary to the CRD-IV presumptions and expectations, the estimated coefficients for the interaction terms of D_varrem and D_def_var with BCC suggest that these tiny mutual banks would achieve less risk taking if left to increase their variable share of remuneration or decrease the deferred variable share in cash. 
Table 6 Logit Regression on Good Performance

\begin{tabular}{|c|c|c|c|}
\hline \multirow[b]{2}{*}{ Regressors } & \multicolumn{3}{|l|}{ Dependent variables } \\
\hline & Good_performance & Good_performance & Good_performance \\
\hline D_varrem & $-69.366^{\text {*** }}$ & - & - \\
\hline D_varrem $^{2}$ & -23.974 & - & - \\
\hline D_varb & - & -71.482 & - \\
\hline D_varb ${ }^{2}$ & - & -136.802 & - \\
\hline D_def_var & - & - & $-166.778^{*}$ \\
\hline D_def_var ${ }^{2}$ & - & - & $395.391^{* * *}$ \\
\hline Size & 0.127 & 0.158 & 0.238 \\
\hline D_Varrem_Size & $8.035^{* * *}$ & - & - \\
\hline D_Varrem²_Size & 4.888 & - & - \\
\hline D_Varb_Size & - & 7.597 & - \\
\hline D_Varb ${ }^{2}$ SSize & - & 14.155 & - \\
\hline D_def_var_Size & - & - & $24.641^{* *}$ \\
\hline D_def_var_Size ${ }^{2}$ & - & - & $-63.347^{* * *}$ \\
\hline D_Varrem_Bcc & $65.283^{* *}$ & - & - \\
\hline D_Varrem ${ }^{2} \_$Bcc & $262.178^{*}$ & - & - \\
\hline D_Varb_Size_Bcc & - & Omitted & - \\
\hline D_Varb_Size ${ }^{2} \_$Bcc & - & Omitted & - \\
\hline D_def_var_Bcc & - & - & $195.583^{* * * *}$ \\
\hline D_def_var ${ }^{2} \_$Bcc & - & - & $-256.776^{* * * *}$ \\
\hline Good_gov & $-1.105^{*}$ & -1.038 & -1.048 \\
\hline Bad_gov & $-1.021^{*}$ & -0.340 & -0.680 \\
\hline Constant & 0.919 & 0.817 & 0.747 \\
\hline No. observations & 90 & 94 & 95 \\
\hline Wald ChiSquare-test & 17.990 & 8.020 & 444.640 \\
\hline Pseudo R-squared & 0.150 & 0.068 & 0.184 \\
\hline
\end{tabular}

Source: authors $*, * *, * * *$ denote the statistical significance at $10 \%, 5 \%$ and $1 \%$, respectively

In addition, also Table 7 - reporting the results of the ordered logit estimation - shows a contradictory result for the efficacy of reducing variable remuneration and of increasing the deferred variable share in cash in terms of lowering risk taking at the SCBs. Indeed, Table 7 reports the following chief results. First, our three remuneration policies work as expected by CRD-IV for the sample as a whole. Increasing the variable share remuneration (D_varrem) or the variable share paid in cash (D_varb) or decreasing the deferred variable share in cash (D_def_var) all reduce the probability that a bank obtains a high degree in terms of its risk taking performance score. Second, however, counterintuitive results are reached for the interactions between the remuneration policy variables and Size. Regarding the D_varrem ordered logit estimation, while Size has a positive effect per se, the interaction of D_varrem with Size as a positive and significant coefficient suggesting that more, not less, variable share remuneration improves performance for larger-sized banks. Also in the D_varb regression the interaction of D_varb - and of its squared - with Size deliver positive effects on performance. And, in the D_def_var specification the negative quadratic interaction of D_def_var2 with Size dominates the positive linear interaction of D_def_var with Size. 
Third, the most important result for us, here too, the positive and significant coefficient of the interaction term between D_varrem and BCC suggests that these tiny mutual banks would achieve less risk taking if left to increase their variable share of remuneration, contrary to the CRD-IV presumptions and expectations. Moreover, regarding the interaction terms of BCC with D_def_var and D_def_var2 we can easily calculate that the quadratic term - bearing a negative signed coefficient - dominates the linear term - delivering a positive signed coefficient. Hence, overall remuneration policies that appear to have some desirable effects for the other banks do not seem to be working for the tiny mutual Banche di Credito Cooperativo.

Table 7 Ordered Logit Regression on the Degree of Good_performance

\begin{tabular}{|c|c|c|c|}
\hline \multirow[b]{2}{*}{ Regressors } & \multicolumn{3}{|l|}{ Dependent variables } \\
\hline & $\begin{array}{l}\text { Degree of } \\
\text { Good_performance }\end{array}$ & $\begin{array}{l}\text { Degree of } \\
\text { Good_performance }\end{array}$ & $\begin{array}{l}\text { Degree of } \\
\text { Good_performance }\end{array}$ \\
\hline D_varrem & $-47.343^{* *}$ & - & - \\
\hline D_varrem ${ }^{2}$ & 20.054 & - & - \\
\hline D_varb & - & $-62.217^{*}$ & - \\
\hline D_varb ${ }^{2}$ & - & $-138.391^{*}$ & - \\
\hline D_def_var & - & - & $-34.816^{*}$ \\
\hline D_def_var ${ }^{2}$ & - & - & $81.028^{*}$ \\
\hline Size & $0.300^{*}$ & 0.099 & 0.032 \\
\hline D_Varrem_Size & $6.495^{* *}$ & - & - \\
\hline D_Varrem²_Size & 2.102 & - & - \\
\hline D_Varb_Size & - & $7.600^{*}$ & - \\
\hline D_Varb ${ }^{2}$ SSize & - & $16.887^{*}$ & - \\
\hline D_def_var_Size & - & - & $5.105^{* *}$ \\
\hline D_def_var__Size & - & - & $-13.014^{* *}$ \\
\hline Italy & -0.466 & 0.904 & 0.866 \\
\hline $\mathrm{Bcc}$ & $2.240^{*}$ & -0.811 & -0.472 \\
\hline D_Varrem_Bcc & $40.892^{* * * *}$ & - & - \\
\hline D_Varrem_2_Bcc & 106.779 & - & - \\
\hline D_Varb_Size_Bcc & - & Omitted & - \\
\hline D_Varb_Size ${ }^{2}$ Bcc & - & Omitted & - \\
\hline D_def_var_Bcc & - & - & $40.908^{* *}$ \\
\hline D_def_var ${ }^{2} \_$Bcc & - & - & $-52.414^{* *}$ \\
\hline Good_gov & 0.054 & -0.201 & -0.242 \\
\hline Bad_gov & $-0.939^{*}$ & -0.227 & -0.538 \\
\hline No. observations & 90 & 94 & 95 \\
\hline Wald ChiSquare-test & $27.010^{*}$ & 25.960 & 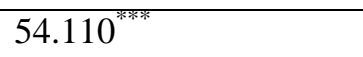 \\
\hline Pseudo R-squared & 0.076 & 0.021 & 0.056 \\
\hline
\end{tabular}

Source: authors $*, * *, * * *$ denote the statistical significance at $10 \%, 5 \%$ and $1 \%$, respectively

\section{Conclusions}

As a reaction to the unsustainable risks taken by banks in the lead up to the GFC, most constituencies stiffened bank regulation. The regulatory restriction took the shape of higher and better quality capital requirements, but it also tried to limit the incentives to risk taking affecting managers via changing their remuneration structure. In this respect, in 
Europe, the CRD-IV Directive introduced some provisions limiting variable remuneration in order to try to mitigate danger of excessive risk taking behaviour in the financial sector.

While the origin of the crisis is typically ascribed to larger-sized, more complex and profit-oriented banking institutions, the one-size-fits-all approach subscribed by European regulators meant that all European banks, irrespective of their size, complexity and profit orientation were subjected to the same rules. In this paper, we asked whether the application of the CRD-IV rules on compensation were appropriate for small cooperative banks (SCBs). Specifically, while such approach makes sense for profit maximizing banks, it could be faulty to tame risk exposures at SCBs that do not have profit maximization as their (sole) objective, are small-sized and not complex. We tested our contention via unique data freshly assembled by an ad-hoc survey on manager compensation, internal governance and banks risk taking in Europe before and after the introduction of CRD-IV. Our results show that changes in remuneration schemes caused by CRD-IV did not induce less risk taking in SCBs. Our evidence also demonstrates that the changes in internal governance derived from the CRD-IV remuneration rules are not clearly associated with risk exposure.

These results support the position of the European Commission which, as suggested by EBA (2015, 2016), in 2016 published a number of proposed amendments to CRD-IV among which the provision on reducing the burden of the remuneration rules for smaller and less complex banking institutions and individuals with variable remuneration below certain thresholds. This provision is included in the so-called CRD-V package that, once approved by the European Parliament and Council of Ministers, is expected to take effect on 1 Jan 2021.

\section{References}

Aebi V., Sabato G., Schmid M. (2012), Risk management, corporate governance and bank performance in the financial crisis, Journal Banking \& Finance 36(12), p. 3213-3226.

Bai G., Elyasiani E. (2013), Bank stability and managerial compensation, Journal of Banking \& Finance 37(3), p. 799813.

Balachandran S., Kogut B., Harnal H. (2011), Did executive compensation encourage extreme risk-taking in financial institutions?, Unpublished, Columbia University.

Bekkum S.V. (2016), Inside debt and bank risk, Journal of Financial and Quantitative Analysis, forthcoming.

Beltratti A., Stulz R.M. (2012), The credit crisis around the globe: why did some banks perform better?, Journal of Financial Economics 105(1), p. 1-17.

Bennett R.L., Guntay L., Unal H. (2015), Inside debt, bank default risk and performance during the crisis, Journal of Financial Intermediation 24(4), p. 487-513.

Berger A.N., Imbierowicz B., Rauch C. (2014), The roles of corporate governance in bank failures during the recent financial crisis, Unpublished.

BIS (2015), Corporate governance principles for banks. Guidelines, Bank for International Settlements, Basel.

Bolton P., Mehran H., Shapiro J. (2015), Executive compensation and risk-taking, Review of Finance 19(6), p. 21392181.

Chen C.R., Steiner T.L., Whyte A.M. (2006), Does stock option-based executive compensation induce risk-taking? An analysis of the banking industry, Journal of Banking \& Finance 30(3), p. 915-945.

Chesney M., Stromberg J., Wagner A.F. (2012), Risk-taking incentives and losses in the financial crisis, Research Paper 10-18, Swiss Finance Institute, Geneva.

DeYoung R., Peng E.Y., Yan M. (2013), Executive compensation and business policy choices at US commercial banks, Journal of Financial and Quantitative Analysis 48(1), p. 165-196.

Dolde W., Knopf J.D. (2006), Impact of corporate ownership and governance on risk-taking and returns at thrift institutions, Unpublished, University of Connecticut.

Ellul A., Yerramilli V. (2013), Stronger risk controls, lower risk: Evidence from U.S. bank holding companies, Journal of Finance 68(5), p. 1757-1803.

Erkens D.H., Hung M., Matos P. (2012), Corporate governance in the 2007-2008 financial crisis: evidence from financial institutions worldwide, Journal of Corporate Finance 18(2), p. 389-411.

European Banking Authority (2015), Opinion of the European Banking Authority on the application of the principle of proportionality to the remuneration provisions in Directive 2013/36/EU, 21 December.

European Banking Authority (2016), Review of the application of the principle of proportionality to the remuneration provisions in Directive 2013/36/EU, 21 November. 
European Union (2013), Directive 2013/36/EU of the European Parliament and of the Council of 26 June on access to the activity of credit institutions and the prudential supervision of credit institutions and investment firms, amending Directive 2002/87/EC and repealing Directives 2006/48/EC and 2006/49/EC (1), Official Journal of the European Union, vol. 56.

Fahlenbrach R., Stulz R.M. (2011), Bank CEO Incentives and the credit crisis, Journal of Financial Economics 99(1), p. 11-26.

Ferri G., Kalmi P., Kerola E. (2015), Organizational structure and performance in European banks: a reassessment, Advances in the Economic Analysis of Participatory \& Labor-Managed Firms 16, p. 109-141.

Forssbaeck J. (2011), Ownership structure, market discipline and banks' risk-taking incentives under deposit insurance, Journal of Banking and Finance 35(10), p. 2666-2678.

Gropp R., Köhler M. (2010), Bank owners or bank managers: who is keen on risk? Evidence from the financial crisis, Discussion Paper 10-013, Zentrum für Europäische Wirtschaftsforschung GMBH, Mannheim, Germany.

Hagendorff J., Vallascas F. (2011), CEO pay incentives and risk-taking: Evidence from bank acquisitions, Journal of Corporate Finance 17(4), p. 1078-1095.

Hesse H., Ĉihák M. (2007), Cooperative banks and financial stability, IMF Working Paper WP/07/2.

Iannotta G., Nocera G., Sironi A. (2007), Ownership structure, risk and performance in the European banking industry, Journal of Banking and Finance 31(7), p. 2127-2149.

International Monetary Fund (2014), Risk-taking by banks: the role of governance and executive pay, in "Global Financial Stability Report: Risk-taking, liquidity, and shadow banking: Curbing excess while promoting growth", Washington D.C..

Jokivuolle E., Keppo J. (2014), Bankers' compensation: sprint swimming in short bonus pools?, Research Discussion Paper 2-2014, Bank of Finland, Helsinki.

Keys B.J., Mukherjee T., Seru A., Vig V. (2009), Financial regulation and securitization: Evidence from subprime loans, Journal of Monetary Economics 56(5), p. 700-720.

Laeven L., Levine R. (2009), Bank governance, regulation and risk taking, Journal of Financial Economics 93(2), p. 259-275.

Liikanen E., Bänziger H., Campa J.M., Gallois L., Goyens M. (2012), High-level Expert Group on reforming the structure of the EU banking sector, Final Report, High-level working Group on reforming the structure of the EU banking sector, Brussels.

Lingel A., Sheedy E. (2012), The influence of risk governance on risk outcomes - International evidence, Macquarie Applied Finance Centre Research Paper No. 37.

Smolders N., Koetsier I., de Vries B. (2012), Performance of European cooperative banks in the recent financial and economic crisis, in "Mooij J. \& Boonstra. W.W. (Eds.), Raiffeisen's Footprint: The Cooperative Way of Banking", Amsterdam: VU University Press, p. 67-86.

Tung F., Wang X. (2011), Bank CEOs, inside debt compensation, and the global financial crisis, Working Paper 11-49, Boston University School of Law, Boston.

Vallascas F., Hagendorff J. (2013), CEO Bonus Remuneration and Bank Default Risk: Evidence from the U.S. and Europe, Financial Markets. Institutions and Instruments 22(2), p. 47-89. 